уширения снижается (см. рис. 2), что не противоречит существующим положениям современной теории прокатки. Некоторый рост коэффициента уширения при увеличении натяжения $\left(1-\frac{\sigma_{1}}{\sigma_{s}}\right)$ от 1 до 0,5 в первом и втором опытах, объясняется увеличением обжатия.

Выводы. В работе показана адекватность эмпирической формулы, предлагаемой для инженерных расчетов, и возможность использования математической модели на основе программного комплекса QForm 2D/3D при теоретических исследованиях.

Из результатов работы видно, что с увеличением натяжения коэффициент уширения уменьшается, это не противоречит существующим положениям современной теории прокатки.

Использование результатов работы в автоматизированных системах проволочных прокатных станов позволяет разрабатывать инновационные ресурсосберегающие технологии производства катанки на существующем оборудовании со сниженным расходным коэффициентом, по сравнению с существующими.

\title{
ЛИТЕРАТУРА
}

1. Дудник Ю. В., Чернявин С. О., Татарульев А. В. Влияние натяжения раската в межклетьевых промежутках проволочного стана на геометрические размеры катанки. Сталь. 1988. № 12. С. 40-42

2. Грудев А. П. Теория прокатки. М. : Металлургия, 1988. 240 с.

3. Уширение при прокатке в калибрах вытяжной системы «овал - круг» / М. Н. Штода и др. Вісник НТУ «ХПІ». Серія: Інноваційні технологї̈ та обладнання обробки матеріалів у машинобудуванні та металургії. Харків : НТУ «ХПІ», 2016. № 30(1202). C. $79-87$.

4. Бахтинов Ю. Б., Тарасевич Ю. Ф., Пименов А. Ф. К учету влияния межклетьевых сил на величину уширения при непрерывной прокатке. Производство проката. 2007. № 10. C. 2-4.

Поступила в редколлегию 27.08.2020.

УДК 621.774 .35

DOI $\quad 10.31319 / 2519-2884 . t m .2020 .5$

СОЛОВЙОВА І.А., к.т.н., доцент

НИКОЛАСНКО Ю.М, ст. викладач

Національна металургійна академія України, м. Дніпро

\section{АНАЛІЗ ТА ПРОГНОЗУВАННЯ ТОЧНОСТІ ТРУБ ПРИ БЕЗОПРАВОЧНОМУ ВОЛОЧІННІ}

Вступ. Дослідженню вдосконалення технології безоправочного волочіння присвячено багато наукових робіт сучасних вчених: Орлова Г.А, Каргіна Б.В., Окулова Р.А., Паршина С.В. та інших. Ці роботи спрямовані на вивчення: волочіння в блок волок; волочіння через волоку, що обертається; моделювання процесу волочіння.

У роботах вирішуються питання, що дозволяють збільшити ступінь деформації при волочінні, продуктивність, зв'язати зміни товщини стінки з енергосиловими параметрами процесів. У світі сучасних вимог до точності труб виникає інтерес до проблеми зміни різностінності труб після волочіння для прогнозування точності готових труб. 
Постановка задачі. Метою даної роботи є дослідження впливу технологічних параметрів безоправочного волочіння труб з різних марок сталей та визначення факторів, що впливають на зміну різностінності труб за допомогою кореляційно-регресійного аналізу.

Результати роботи. Безоправочному волочіння піддають труби після короткооправочного волочіння або прокатки на станах ХПТ або ХПТР, тобто труби, які мають певну різностінність.

3 метою оцінки точності труб після безоправочного волочіння були спроектовані та досліджені технологічні маршрути виробництва труб з різних марок сталей. За розробленими маршрутами за технологією виробництва протягалися партії труб [1], від кожної партії відбиралися зразки і проводилися виміри товщини стінки в рівновіддалених точках поперечного перерізу труби.

Для кожного проходу волочіння розраховані: абсолютна $\Delta t=t_{\max }-t_{\min }$ і відносна різностінність заготовки $\delta_{0}=\frac{\Delta t_{0}}{t_{0 \text { сарp }}}$ і готової труби $\delta=\frac{\Delta t}{t_{\text {cåp }}}$; коефіцієнт обтиснення по діаметру $\frac{D_{0}}{D}$; ступінь тонкостінності $\frac{t_{0}}{D_{0}}$; ступінь деформації $\varepsilon$; коефіцієнт зміни різностінності $k=\frac{\delta}{\delta_{0}}$.

За результатами вимірювань виконаний кореляційно-регресійний аналіз, визначені фактори, що впливають на зміну різностінності і побудовані регресійні моделі $[1,3]$.

Інтервали варіювання вихідними даними наведені в таблиці 1.

Таблиця 1 - Інтервали варіювання вихідних даних для аналізу

\begin{tabular}{|c|c|c|}
\hline \multirow{2}{*}{ Параметр } & \multicolumn{2}{|c|}{ Діапазон варіювання параметру } \\
\cline { 2 - 3 } & нержавіючі сталі & вуглецеві сталі \\
\hline$\delta_{0}, \%$ & $0,80 \ldots 13,5$ & $1,2 \ldots 16,5$ \\
\hline$\frac{D_{0}}{D}$ & $1,12 \ldots 1,5$ & $0,02 \ldots 0,21,6$ \\
\hline$\frac{t_{0}}{D_{0}}$ & $0,05 \ldots 0,235$ & $10,16,25,36$ \\
\hline$D_{0}$ & \multicolumn{3}{|c}{$0,97 \ldots 3,0$} \\
\hline$t_{0}$ & \multicolumn{3}{|c}{} \\
\hline
\end{tabular}

Як випливає з визначення при $k<1$ різностінність зменшується, при $k>1$ різностінність готової труби більше різностінності заготовки.

Значимість коефіцієнтів отриманих рівнянь оцінювалася за критерієм Стьюдента, а адекватність моделі за критерієм Фішера. Отримані моделі є адекватними і зі значимими коефіцієнтами [1-3]. Деякі моделі наведені в таблиці 2.

В результаті розрахунків отримані коефіцієнти множинної кореляції, коефіцієнти регресії для моделей лінійного, гіперболічного та параболічного типу. За результатами кореляційно-регресійного аналізу сформовані рівняння регресії аналізувалися $\mathrm{i}$ уточнювалися. 3 вивчених моделей обрані моделі типу А і В (таблиці 2, 3), які адекватно відображають досліджувану залежність. 
Таблиця 2 - Коефіцієнти різностінності моделі типу А

\begin{tabular}{|c|c|}
\hline Сталь & Коефіцієнти різностінності \\
\hline 08Х22Н6Т & $k=1,681+\frac{3,304}{\delta_{0}}-0,522 \frac{D_{0}}{D}-10,110 \frac{t_{0}}{D_{0}}+29,128\left(\frac{t_{0}}{D_{0}}\right)^{2}-0,003 \varepsilon$ \\
\hline 06ХН28МДТ & $k=1,126+\frac{3,015}{\delta_{0}}-1,177 \frac{D_{0}}{D}+8,097 \frac{t_{0}}{D_{0}}-27,980\left(\frac{t_{0}}{D_{0}}\right)^{2}-0,003 \varepsilon$ \\
\hline ХН77ТЮР & $k=1,678+\frac{1,727}{\delta_{0}}-0,246 \frac{D_{0}}{D}-16,494 \frac{t_{0}}{D_{0}}+69,167\left(\frac{t_{0}}{D_{0}}\right)^{2}-0,003 \varepsilon$ \\
\hline 10 & $k=1,974+\frac{2,324}{\delta_{0}}-0,718 \frac{D_{0}}{D}-8,442 \frac{t_{0}}{D_{0}}+23,616\left(\frac{t_{0}}{D_{0}}\right)^{2}-0,003 \varepsilon$ \\
\hline
\end{tabular}

Таблиця 3 - Коефіцієнти різностінності-моделі типу В

\begin{tabular}{|c|c|}
\hline Сталь & Коефіцієнти різностінності \\
\hline 08 Х22Н6Т & $k=1,463+\frac{3,374}{\delta_{0}}-0,796 \frac{D_{0}}{D}-1,862 \frac{t_{0}}{D_{0}}$ \\
\hline 06ХН28МДТ & $k=1,391+\frac{3,068}{\delta_{0}}-0,959 \frac{D_{0}}{D}-0,197 \frac{t_{0}}{D_{0}}$ \\
\hline ХН77ТЮР & $k=0,812+\frac{1,709}{\delta_{0}}-0,265 \frac{D_{0}}{D}+0,557 \frac{t_{0}}{D_{0}}$ \\
\hline 10 & $k=1,615+\frac{2,216}{\delta_{0}}-0,667 \frac{D_{0}}{D}-1,994 \frac{t_{0}}{D_{0}}-0,002 \varepsilon$ \\
\hline
\end{tabular}

Встановлено, що в моделях типу А всі коефіцієнти значимі, а в моделях типу В коефіцієнт при $\frac{t_{0}}{D_{0}}$ не завжди опинявся значущим, тобто залежність від $\frac{t_{0}}{D_{0}}$ не слід вважати лінійної, що підтверджує модель типу А.

Інтенсивність виправлення $(k<1)$ залежить від коефіцієнта обтиснення по діаметру $\frac{D_{0}}{D}$ : чим більше значення $\frac{D_{0}}{D}$, тим інтенсивніше виправлення різностінності. Тобто 3 метою виправлення різностінності ( $\left.\delta_{0}>4 \%\right)$ при безоправочному волочінні необхідно збільшувати коефіцієнт витяжки.

Проаналізовано залежність коефіцієнта зміни різностінності від різностінності заготовки (таблиця 4).

Характер залежності ідентичний. При малій різностінності заготовки (менше 3\%) різностінність готових труб зростає, при різностінності заготовки $3 . .4 \%$ різностінність готових труб змінюється мало і при $\delta_{0}>4 \%$ різностінність готових труб зменшується.

Таким чином, прогнозуючи очікувану поперечну різностінність готової труби після безоправочного волочіння можна використовувати регресивну залежність наведену в таблиці 5.

При аналізі отриманих залежностей [1-3] можна зробити деякі висновки: чим пластичніше метал, тим менше зміна різностінності. Менш пластичні сталі мають більшу тенденцію до зміни різностінності. При малих значеннях $\delta_{0}$ коефіцієнт $k$ досягає 
величини 3,5 , тобто різностінність збільшується в 3,5 рази, а при великих значеннях $\delta_{0}$ інтенсивніше ії виправлення. Інтенсивність виправлення $(k<1)$ залежить від коефіцієнта обтиснення по діаметру $\frac{D_{0}}{D}$ : чим більше значення $\frac{D_{0}}{D}$, тим інтенсивніше виправлення різностінності. Тобто з метою виправлення різностінності ( $\left.\delta_{0}>4 \%\right)$ при безоправочному волочінні необхідно збільшувати коефіцієнт витяжки.

Таблиця 4 - Залежність коефіцієнту зміни різностінності від різностінності заготовки

\begin{tabular}{|c|c|}
\hline Сталь & Коефіцієнти зміни різностінності від різностінності заготовки \\
\hline 08Х22Н6Т & $k=0,1866+\frac{3,3038}{\delta_{0}}$ \\
\hline 06ХН28МДТ & $k=0,2366+\frac{3,0149}{\delta_{0}}$ \\
\hline ХН77ТЮР & $k=0,4113+\frac{1,7271}{\delta_{0}}$ \\
\hline 10 & $k=0,3584+\frac{2,3235}{\delta_{0}}$ \\
\hline
\end{tabular}

Таблиця 5 - Прогнозування різностінності

\begin{tabular}{|c|c|}
\hline Сталь & Прогнозування різностінності \\
\hline 08 Х22Н6Т & $\delta_{s 1}=3,304+\delta_{s 0}\left(1,681-0,522 \frac{D_{0}}{D}-10,110 \frac{t_{0}}{D_{0}}+29,128\left(\frac{t_{0}}{D_{0}}\right)^{2}-0,003 \varepsilon\right)$ \\
\hline ХН77ТЮР & $\delta_{s 1}=1,727+\delta_{s 0}\left(1,678-0,246 \frac{D_{0}}{D}-16,494 \frac{t_{0}}{D_{0}}+69,167\left(\frac{t_{0}}{D_{0}}\right)^{2}-0,003 \varepsilon\right)$ \\
\hline 10 & $\delta_{s 1}=2,324+\delta_{s 0}\left(1,974-0,718 \frac{D_{0}}{D}-8,442 \frac{t_{0}}{D_{0}}+23,616\left(\frac{t_{0}}{D_{0}}\right)^{2}-0,003 \varepsilon\right)$ \\
\hline
\end{tabular}

де $\delta_{s 0}-$ поперечна різностінність вихідної заготовки; $\delta_{s 1}-$ поперечна різностінність готової труби.

Висновок. Результати досліджень впроваджені в розрахунки маршрутів та технологічних карт виробництва [2] 3 метою прогнозування різностінності готових труб при волочінні та запровадженню скорочення витрат металу на виробництві.

\section{ЛІТЕРАТУРА}

1. Соловьева И. А. Разработка многовариантной технологии, исследование и внедрение рациональных режимов производства холоднодеформированных труб : дис. канд. техн. наук : 05.16.05. Днепропетровск, 1987. 200 с.

2. Соловйова І. А., Балакін В. Ф., Николаєнко Ю. М., Білан К. С. Проектування комбінованих маршрутів виробництва холоднодеформованих труб. Системні технології. 2017. № 4. С. 56-62.

3. Соловйова І. А., Николаєнко Ю. М. Прогнозування точності труб при безоправочному волочінні. Системні технологіï. 2020. № 5. С. 30-36. 